\title{
MINERAL RESOURCE POTENTIAL OF THE MIDDLE MOUNTAIN-TOBACCO ROOT ROADLESS AREA, MADISON COUNTY, MONTANA
}

\author{
By \\ J. Michael O'Neill, U.S. Geological Survey \\ and \\ Eric Cather and J. Mitchell Linne, U.S. Bureau of Mines
}

\section{STUDIES RELATED TO WILDERNESS}

Under the provisions of the Wilderness Act (Public Law 88-577, September 3, 1964) and related acts, the U.S. Geological Survey and the U.S. Bureau of Mines have been conducting mineral surveys of wilderness and primitive areas. Areas officially designated as "wilderness," "wild," or "canoe" when the act was passed were incorporated into the National Wilderness Preservation System, and some of them are presently being studied. The act provided that areas under consideration for wilderness designation should be studied for suitability for incorporation into the Wilderness System. The mineral surveys constitute one aspect of the suitability studies. The act directs that the results of such surveys are to be made available to the public and be submitted to the President and the Congress. This report discusses the results of a mineral survey of the Middle Mountain-Tobacco Root Roadless Area (B1013), Deerlodge and Beaverhead National Forests, Madison County, Mont. The Middle Mountain-Tobacco Root Roadless Area was classified as a further planning area during the Second Roadless Area Review and Evaluation (RARE II) by the U.S. Forest Service, January 1979.

\section{MINERAL RESOURCE POTENTIAL SUMMARY STATEMENT}

The Middle Mountain-Tobacco Root Roadless Area of southwestern Montana contains areas of low to high mineral resource potential (fig. 3). The areas of highest potential are in or adjacent to intrusive rocks of Late Cretaceous age.

Most of the roadless area is underlain by Archean metamorphic and igneous rocks that are locally overlain by Paleozoic and Mesozoic sedimentary rocks; all rocks have been intruded by the Late Cretaceous Tobacco Root batholith or its apophyses. Metamorphic rocks adjacent to the batholith, and metamorphic and sedimentary rocks intruded by apophyses of the batholith, commonly show some sulfide mineralization. Disseminated and stockwork copper and molybdenum sulfides are present at Granite Peak in that part of the batholith that extends into the roadless area. Sulfide-bearing breccia pipes on Middle Mountain appear to be related to this mineralized zone. The Granite Peak area exhibits high mineral resource potential for copper and molybdenum.

Apophyses of the Tobacco Root batholith are present in the Boulder Lakes area, partly within the roadless area. Many of these intrusive bodies bear minor disseminated or weakly developed stockwork sulfides and local fluorite and are associated with quartz veins that contain important amounts of gold. A weakly mineralized breccia pipe is also present in the Boulder Lakes area, as well as gold-bearing quart $z$ veins that have been actively mined. Two properties in this area, the Snyder mine and the Curly Bill-Curly Bill No. 2 claims, have identified resources totalling about 90,000 tons. Gold resources at depth are indicated for the nearby Boulder Cobalt, Curly Bill No. 3, Midnight, and Old Cabin prospects. The Boulder Lakes area displays moderate to high mineral resource potential for precious metals, especially gold, and a low to moderate potential for base-metal sulfides.

The Strawn Mine, near the mouth of Beall Creek, is an active gold mine that is nearly surrounded by the roadless area. The main vein at this mine can be traced southward into the roadless area. The Nicholson (Ridgeway) mine, an active gold mine located along the Bismark fault zone, is not within the the roadless area but is essentially surrounded by it. The Strawn and Nicholson mines have identified gold resources of about 28,000 tons. The Nicholson mine, the now inactive Bismark mine at the north end of Middle Mountain, and the nearby Baugus Hughes, Moggolian, Lester Baker, Quartz City, and Sultana prospects explore major mineralized areas along the Bismark fault zone. Sulfide mineralization and associated gold-bearing quartz veins are more common along this fault zone than along any other structural feature in the northern Tobacco Root Mountains. These areas show high potential for precious metals. Areas along the Bismark fault zone adjacent to the Bismark mine also show moderate to high potential for base metals.

Many of the streams that provide water for irrigation of lands adjacent to the Tobacco Root Mountains have their headwaters in glacial cirques in or adjacent to the roadless area. The value of this resource is very high. 


\section{INTRODUCTION}

The Middle Mountain-Tobacco Root Roadless Area encompasses 36,640 acres, mainly within the Deerlodge and Beaverhead National Forests, Madison County, Mont. (fig. 1). The area studied for this report includes the roadless area and parts of the national forest peripheral to it.

The Tobacco Root Mountains are a linear, northtrending range bounded on the east and west by broad intermontane valleys. The highest peaks of the range occur within the roadless area, reaching a maximum elevation of $10,604 \mathrm{ft}$ on $\mathrm{Mt}$. Jefferson. Topographic relief is nearly $5,000 \mathrm{ft}$ along the western part of the range. The roadless area encompasses nearly all of the drainage basin of the South Boulder River, a northflowing tributary of the Jefferson River. The headwaters of this drainage system are in a ring of north-facing cirques that mark the formidable southern boundary of the roadless area. Middle Mountain is the prominent peak on the ridge that trends northward into the center of the cirque complex.

\section{GEOLOGY}

Rocks exposed in the Tobacco Root Mountains range in age from Precambrian to Quaternary. A detailed geologic map is given by O'Neill (1983a). The core of the range is composed of two major rock types: layered Archean rocks in much of the northern, western, and southern parts of the range, and dioritic to granitic batholithic rocks of Late Cretaceous age in much of the east-central part of the range. Sedimentary rocks, mainly Paleozoic in age, are present along the northwest and north margins of the uplift and are remnants of the extensive sedimentary section that once covered the region. These sedimentary rocks, which almost everywhere dip away from the range core, appear to have been draped over the edge of a basement block that was initially uplifted in Late Cretaceous-early Tertiary time (Schmidt, 1975). Basin-fill sediments were shed from this and adjacent uplifts into the intermontane valleys and are now exposed along the west and north margins of the range. Block faulting that raised the range to its present height and position began in late Miocene time and continues today (Pardee, 1950). The range was intensely glaciated in the Pleistocene and contains many cirques, tarns, and ice-carved valleys. Quaternary deposits, largely glacial in origin, commonly blanket the floors of most mountain valleys.

\section{Precambrian metamorphic rocks}

Archean metamorphic rocks of the Tobacco Root Mountains consist mainly of amphibolite-grade quartzofeldspathic gneiss interlayered with varying proportions of calc-silicate rock and marble, quartzite, aluminous schist, anthophyllite- and garnet-rich schist and gneiss, magnetite gneiss, hornblende-plagioclase gneiss, and amphibolite (Vitaliano and others, 1979). The structurally lowest rocks are the most lithologically complex and show the greatest amount of megascopic deformation. All Archean rocks were subjected to strong regional metamorphism and penetrative deformation during a major tectonic event 2.7 b.y. ago (Mueller and Cordua, 1976; James and
Hedge, 1980). These rocks also were affected by a pervasive thermal event about $1.6 \mathrm{~b} . \mathrm{y}$. ago (Giletti, 1966). All rocks have been intruded by Archean metabasite and ultramafic dikes and sills, by Proterozoic diabasic dikes (Wooden and others, 1978), and by granitic pegmatites of probable Precambrian age.

\section{Phanerozoic sedimentary rocks}

Sedimentary rocks exposed in the Tobacco Root Mountains are typical of the southwestern Montana succession (Sloss and Moritz, 1951; Tysdal, 1976) and are exposed along the northwest and north sides of the uplift. Quartz sandstone and minor pebble conglomerate are present at the base of the section and mark the encroachment of Middle Cambrian seas onto the craton (Perry, 1962). Above the sandstone lies a thick succession of interlayered carbonate and fine-grained clastic rocks indicative of a fluctuating shoreline in this area from Middle to Late Cambrian time. A major erosional unconformity marks the contact between the Upper Cambrian sandy shale and Devonian dolomite (Sloss and Moritz, 1951; Tysdal, 1976). A thick succession of Lower Mississippian rocks overlies the Devonian sequence; these Mississippian rocks consist of limestone interlayered with calcareous shale. They grade upward into massive, thick-bedded, cherty limestone. A minor unconformity separates the Mississippian rocks from fine-grained sandstone, black shale and red shale, oolitic phosphatic rock, bedded chert, and minor limestone of late Paleozoic age.

Quaternary sediments are present in the roadless area and are largely confined to the valley floors. These deposits include alluvial sands and gravels, glacial till and outwash, talus, rock glaciers, and minor landslide debris. Alluvial fans and pediment gravels are common along the western margin of the range.

\section{Upper Cretaceous igneous rocks}

The main igneous body in the Tobacco Root Mountains is the Tobacco Root batholith of Late Cretaceous age, dated at 72-77 m.y. (Vitaliano and others, 1976). The batholith is elongate northwestsoutheast, and its intrusion appears to have been controlled in large part by pre-existing, northwesttrending, high-angle faults (Reid, 1957). The pluton is zoned from tonalite and minor hornblende diorite along its margins to a small, elliptical core of granite (Smith, 1970). Diorite and tonalite are present in that part of the batholith exposed in the roadless area. Apophyses of the batholith are common in the southern and western parts of the roadless area. Small plugs, ranging in composition from granodiorite to latite porphyry, intrude Archean rocks of the Boulder Lakes area. Granodioritic to quartz monzonitic sills and mostly concordant plugs intrude the sedimentary rocks exposed along the western margin of the range (Reyner, 1947; Johns, 1961).

\section{Structure}

The rocks of the roadless area are deformed to various degrees. Archean rocks, the most strongly deformed, were folded, faulted and strongly attenuated during metamorphism. Foliation is axial planar (Reid, 1957), but is parallel to, and controlled 


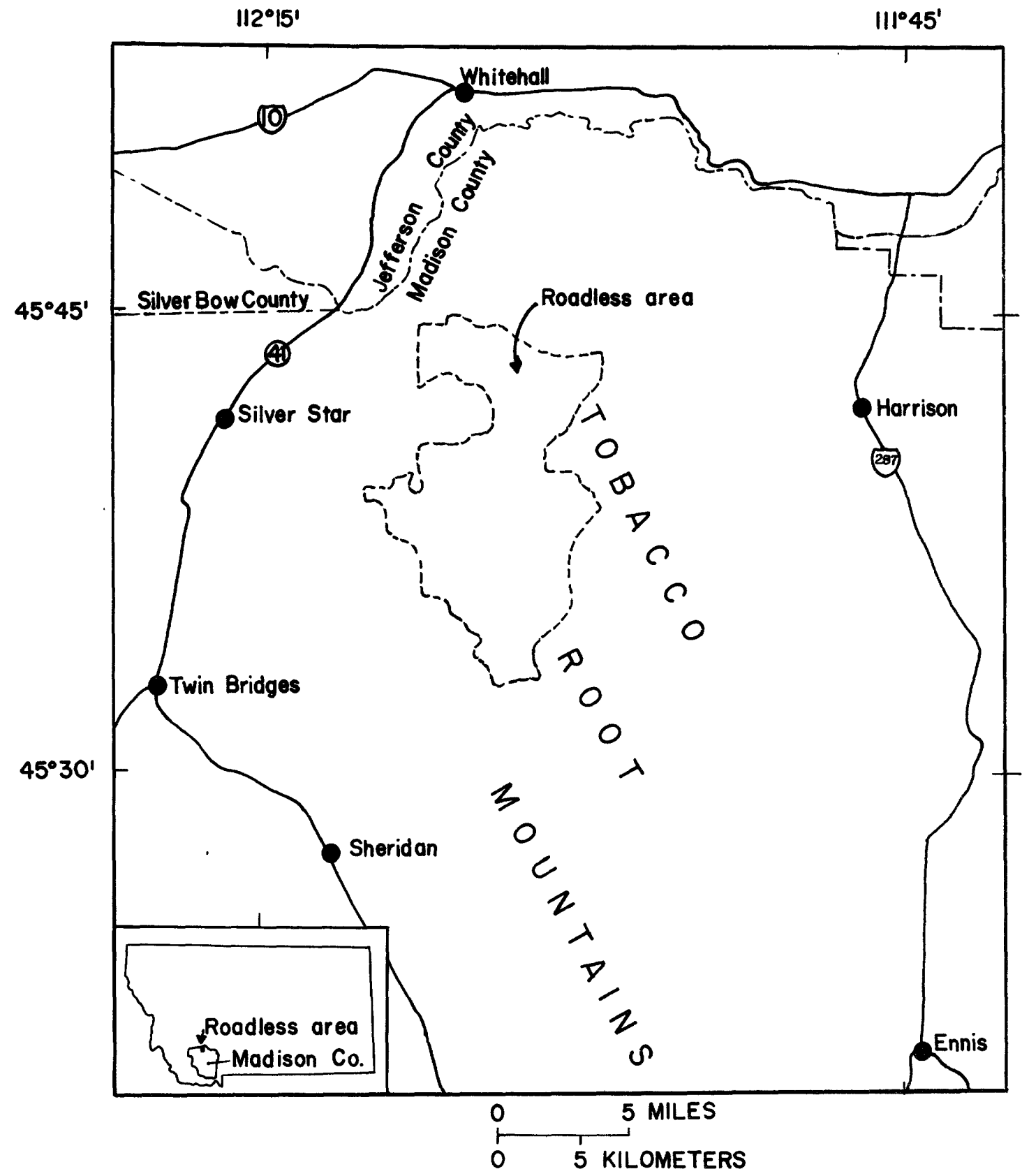

Figure 1.--Index map showing location of the Middle Mountain-Tobacco Root Roadless Area (B1013), Madison County, Mont. 
by, original bedding (Burger, 1967). Megascopic isoclinal folds characterize the structurally lower, multilithologic metamorphic assemblage, whereas a single, broad antiformal fold megascopically deforms the structurally higher quartzofeldspathic gneiss.

The Paleozoic sedimentary rocks have been faulted and folded during several periods of tectonism. Thrust faults of small apparent horizontal displacement that place older upon younger rocks and that are associated with folds overturned to the east are present along the western part of the range. Many of these faults are subparallel to bedding and tend to be localized within shale horizons that separate the carbonate rocks. These shales have been tectonically thinned, internally deformed, and sheared. The sedimentary rocks, thrust faults, and related structures dip steeply to the west at the range front, but east of the front, within the range, they are more gently inclined. The monoclinal aspect of this structure appears to be due to draping over the west edge of the Laramide-age Tobacco Root uplift. To the south, in the Tidal Wave mining district, the sedimentary rocks are folded into broad, open folds and are displaced by minor thrust faults (Johns, 1961).

Two major northwest-trending, high-angle faults cross the roadless area, dividing it into three basement blocks. These faults formed in Precambrian time (Reid, 1957) and show recurrent movement (Schmidt, 1975). Major deformation along these faults occurred in Archean time. Althuugh these faults cut the sedimentary rocks on the north and west sides of the range, the major deformation of the sedimentary succession involved the folding of the sedimentary rocks above these faults (Schmidt, 1976, 1979).

The steep front of the Tobacco Roots along the west side of the range and the associated widespread alluvial-fan development, small fault scarps, slumping, and pronounced alinement of springs are taken as evidence for recent uplift of the Tobacco Root Mountains (Tansley and others, 1933; Alden, 1953). High-angle, north- to northeast-trending faults that cut thrust faults and sedimentary rocks in the Tidal Wave mining district may be related to this youngest period of faulting.

\section{GEOCHEMISTRY}

Geochemical analyses of stream-sediment samples collected in and near the roadless area define several target areas in which anomalously high concentrations of base and precious metals were detected (O'Neill, 1983b).

A major copper and molybdenum anomaly is centered on Granite Peak (fig. 2), partly within the roadless area. Stream-sediment samples collected from this area contain a significant concentration of copper $(1,000 \mathrm{ppm})$ and molybdenum $(100 \mathrm{ppm})$. The anomaly is elliptical in plan, is more than $1 \mathrm{mi}$ across, and is surrounded by a lead-zinc-arsenic-silver halo. The halo is defined by anomalously high concentrations of lead, zinc, and arsenic that were detected in samples collected east of Granite Peak, in samples collected from the headwaters of Wisconsin Creek, Noble Fork, and from streams west of Middle Mountain, and in samples collected from the Middle Mountain breccia pipe and the Bismark Mine, north of Granite Peak.
Geochemical techniques used in this study were not sensitive enough to outline areas of anomalous gold concentrations. The presence, of many mines having significant gold production adjacent to the roadless area indicates a broad area of high gold values. The distribution of these mines is approximately coincident with the location of stream-sediment samples that contained $1 \mathrm{ppm}$ or more of silver. Silver in amounts greater than $0.5 \mathrm{ppm}$ was also detected in most samples collected from the Granite Peak area.

\section{MINING DISTRICTS AND MINERALIZED AREAS}

Several small, overlapping mining districts are adjacent to or partly within the roadless area (fig. 2). Many of the mines were operated in the early 1900's (Tansley and others, 1933). An estimated 200 claims have been located in the roadless area since the 1870 's, and 157 were current in October 1982. These claims include six patented claims, comprising about 91 acres, that are partly or totally within the roadless area and a group of 120 claims covering the head of Beall Creek and the area directly to the east. A list of mines and prospects in or adjacent to the roadless area is given in table 1 , and their locations are shown in figure 2 .

\section{South Boulder mining district}

The South Boulder mining district is in the South Boulder River drainage basin. The Mammoth and Bismark faults have been the main controls in localizing ore minerals in this district. The Mammoth and adjacent mines were the largest producers in this district; they are $0.5 \mathrm{mi}$ outside the roadless area, along the Mammoth fault. At the Mammoth mine, gold was produced from vein-filled fractures associated with the Mammoth fault zone (Tansley and others, 1933). The mine is now inactive, but a cyanide-leaching plant has been constructed to process tailings. Two patented mining claims directly west of the Mammoth mine, the Mountain Boy and Bonanza patents, explore north-trending gold- and copperbearing veins that are adjacent to the roadless area.

Along the Bismark fault, several properties have yielded base and precious metals from fissure veins and disseminated ore. The Bismark mine explores gold-bearing quartz veins localized along the fault where it juxtaposes batholithic and Archean rocks. Copper ore at this mine is disseminated in granitic rocks; however, the Quartz City and Sultana prospects dug along the fault zone about $0.5 \mathrm{mi}$ northwest and north of the mine expose sulfide-bearing quartz veins and silicified rock that contain rare galena and molybdenite. The Nicholson (Ridgeway) and Moggolian mines, and the adjacent Baugus Hughes and Lester Baker properties, about $2 \mathrm{mi}$ southeast of the Bismark mine and on the Bismark fault (fig. 2), expose easttrending quartz veins containing gold and silver. The Nicholson mine produced more than $360 \mathrm{oz}$ of gold from 1900 to 1975 ; in 1980 about $60 \mathrm{oz}$ of gold was recovered from the lode by the present operators. Gold occurs in auriferous pyrite or as fine gold in oxidized parts of the vein.

\section{Tidal Wave and Sheridan mining districts}

Winchell (1914), Tansley and others (1933), and Johns (1961) described many of the mines in the Tidal 
Wave mining district, which includes the area south of Dry Boulder Creek and is partly within the roadless area (fig. 2). The Sheridan mining district includes all mines along Wisconsin, Indian, and Mill Creeks and abuts the Tidal Wave district to the west. Headwaters of these creeks are adjacent to or within the roadless area. About 60 unpatented lode claims and part or all of six patented mining claims are within the roadless area in these two districts. Mines and prospects in the Tidal Wave-Sheridan area have been opened along quartz-rich fissure veins following pre-existing fractures in Archean rocks, or along replacement and contact metasomatic zones in Paleozoic carbonate rocks adjacent to granodiorite or quartz monzonite sills. The quartz veins and sills are presumed to be related to the Tobacco Root batholith. Most deposits yielded gold, silver, and lead, and minor zinc and copper (Johns, 1961). Almost all gold and silver was recovered from narrow fissure veins. The richest parts of the veins are near the surface, where meteoric waters have oxidized and removed gold-bearing sulfide minerals, leaving behind gold-enriched, limonite-filled fractures. Principal deposits of lead and silver are in irregular metasomatic-replacement zones in Cambrian carbonate rocks. Tactite zones adjacent to sills have yielded mainly gold and copper (Johns, 1961). The Tidal Wave and Sheridan mining districts are now largely inactive; however, those mines closed at the beginning of World War II probably have recoverable gold reserves at depth.

No recorded production has come from any mines of the Tidal Wave-Sheridan districts in the roadless area, except from the Old Cabin extension (the Snyder mine), which yielded in a single shipment in 1934,10 oz of gold, $75 \mathrm{oz}$ of silver, and $362 \mathrm{lbs}$ of copper. Extensive but caved workings at the Curly Bill No. 3 prospect suggest that some ore was recovered from this property. The Snyder mine and the Curly BillCurly Bill No. 2 prospect have estimated gold-bearing resources of about 90,000 tons.

Granite Peak, in the southern part of the roadless area, and included within the Sheridan mining district, is the site of a block of 51 claims that is mostly within the roadless area. Granite Peak (fig. 2) is underlain by the northwest-trending lobe of the Tobacco Root batholith that extends into the roadless area. This lobe of the batholith is bounded on the northeast by the northwest-trending Bismark fault zone. The rocks of the batholith in the Granite Peak area are porphyritic hornblende diorite and tonalite (Smith, 1970) that, on the north face of Granite Peak, have been intruded by north-trending dikes, 20 to $30 \mathrm{ft}$ thick, of fine-grained quartz monzonite. Intensely altered and fractured rocks occupy an elliptical area around these dikes. The batholithic rocks adjacent to the dikes contain moderately to strongly chloritized amphiboles, and frayed, light-brown tablets of biotite. The rocks are cut by thin quartz veins and quartz monzonite dikes, which are locally abundant, and by thin stockwork fractures filled with sulfides. The rocks contain disseminated copper and molybdenum minerals and display pronounced fracturing and limonite staining. Sulfides are also common along east-trending faults and fractures south of Granite Peak, outside the major alteration zone.

On Middle Mountain, about $1 \mathrm{mi}$ north of the mineralized area of Granite Peak (fig. 2), two mineralized breccia pipes have intruded Archean quart z-feldspar-biotite gneiss and amphibolite. These pipes are exposed on the north side of Middle Mountain but are partly covered by talus; they probably are connected with one another at depth. They occupy an elliptical area nearly $0.5 \mathrm{mi}$ long and $0.2 \mathrm{mi}$ wide. Breccia in the pipes consists of angular fragments of Archean gneiss. The breccia is stained yellow-orange and contains abundant veinlets of pyrite. Rock samples from the pipe contain significant amounts of silver, arsenic, molybdenum, and zinc. The pipes are probably related to the hydrothermal mineralization at Granite Peak, and may be the surface expression of an important subsurface extension of the mineralized zone.

\section{Renova mining district}

The Renova mining district includes the northwestern and northern slopes of the Tobacco Root Mountains north of Dry Boulder Creek (fig. 2). Production from the district has come mainly from gold mines $5 \mathrm{mi}$ or more north of the roadless area. Two properties in this district are adjacent to the roadless area.

An isolated, narrow gold vein is being mined in the lower part of Beall Creek, in the Strawn Mine (fig. 2). This vein is in a contact metasomatic zone in the Cambrian Meagher Limestone adjacent to a thin, altered mafic dike (Tansley and others, 1933). The main workings are almost completely surrounded by the roadless area. At least $1,600 \mathrm{oz}$ of gold has been mined from the oxidized parts of silicified limestone at the Strawn mine. A narrow mineralized zone is present south of the Strawn mine at the Ohio Lode property; more than $1,500 \mathrm{oz}$ of gold and $2,700 \mathrm{oz}$ of silver were recovered from this mine.

\section{ASSESSMENT OF MINERAL RESOURCE POTENTIAL}

The assessment of mineral resource potential is based on the following criteria: (1) structural and stratigraphic environments favorable for the occurrence of ore minerals; (2) visible mineralized rock or patterns of altered rock associated with ore minerals; (3) the presence of anomalously high concentrations of base or precious metals or of pathfinder elements in stream sediments; and (4) the historic presence of prospecting or mining activity. A high resource potential requires that all of the above criteria are met. A moderate resource potential indicates that some of the above criteria are met but that further exploration is required. A low resource potential indicates that none of the above criteria are met.

\section{Base metals}

The Granite Peak area (fig. 3) is interpreted to represent a major hydrothermal porphyry system by virtue of: (1) the high values of copper and molybdenum in both stream sediment and rocks; (2) the abundance of quartz veins and disseminated sulfides over an area more than $1 \mathrm{mi}$ in diameter; (3) the anomalous lead-zinc-silver-gold metal zonation around the Granite Peak copper-molybdenum anomaly; and (4) the presence of a nearby mineralized breccia pipe. The immediate area around Granite Peak is assigned a high potential for copper and molybdenum resources. 


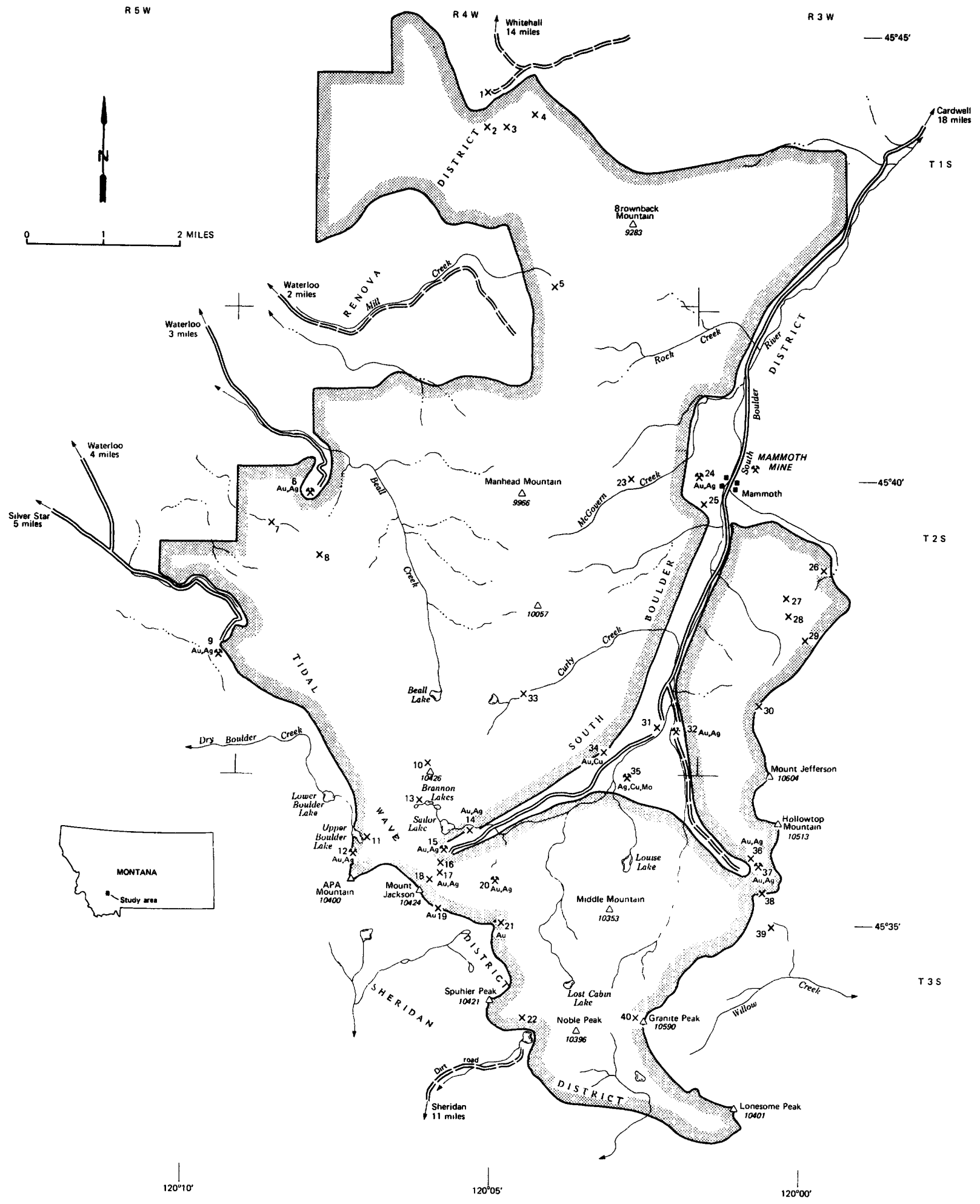

Figure 2.--Map showing the location of the Middle Mountain-Tobacco Root Roadless Area relative to mines and prospects, mining districts, and main geographic features mentioned in text. 
EXPLANATION

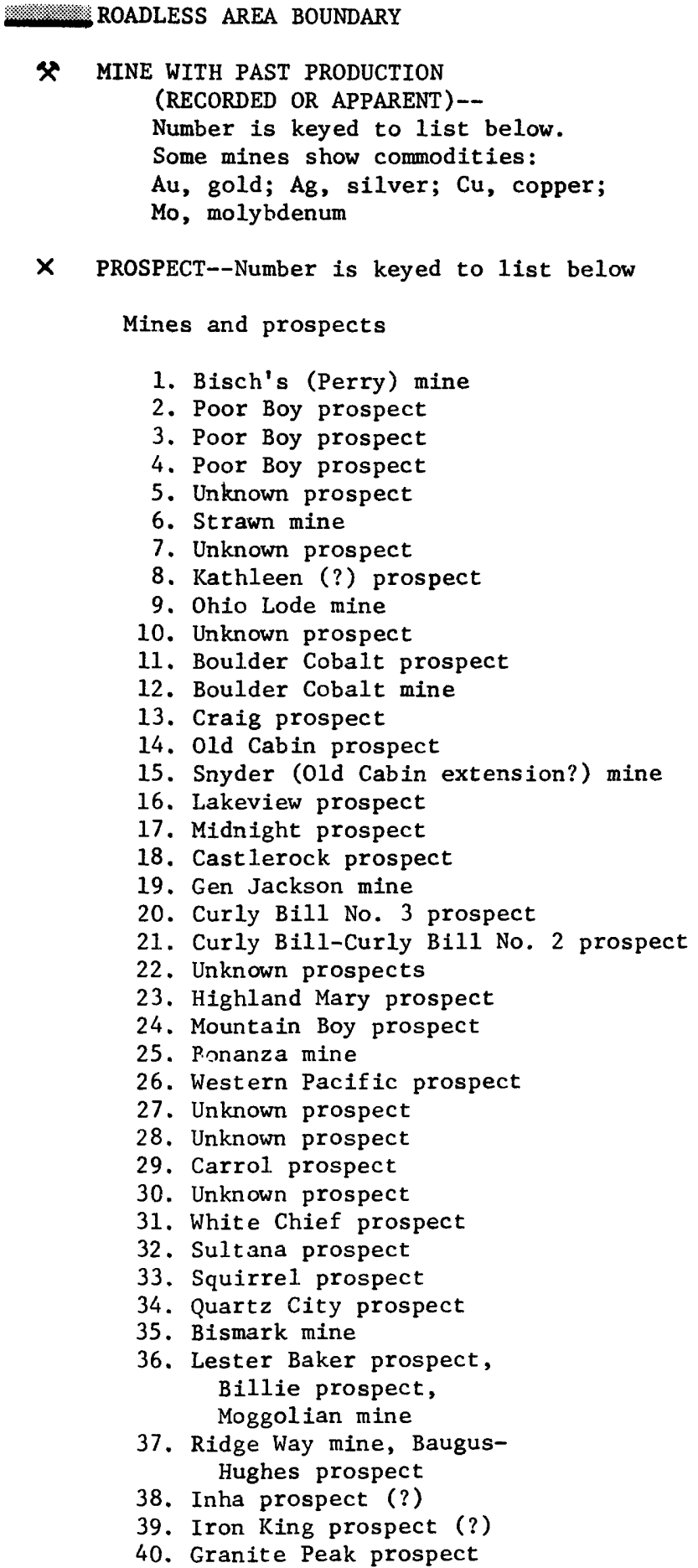

Figure 2.--Cont inued. 
The inactive Bismark Mine is directly north of Middle Mountain (fig. 2) and has produced significant amounts of both base and precious metals; some stream-sediment samples from this area showed anomalously high base-metal values. The mine and the adjacent Quartz City and Sultana prospects explore veins that are localized along faults and shear zones that are associated with the northwest-trending Bismark fault zone and are peripheral to the Granite Peak copper-molybdenum anomaly. The area adjacent to the fault zone near and southeast of the Bismark mine is considered to have high potential for resources of both base and precious metals.

Lead, zinc, and silver ore commonly is found around the margins of porphyry copper and molybdenum deposits throughout the North American cordillera. The base-metal halo around Granite Peak is in keeping with this observed mineral zonation and is considered to be indicative of a moderate base-metal mineral resource potential in this area (fig. 3 ).

Small bodies of quartz monzonite, granodiorite, and related rocks intrude the Archean metamorphic rocks in the roadless area; most of these bodies contain small veinlets or disseminations of sulfide minerals. One small body of porphyritic latite exposed west of the Boulder Lakes (fig. 2) contains disseminated fluorite along with sulfide minerals. A small, weakly mineralized pipe of breccia similar to that on Middle Mountain is present at the roadless area boundary directly east of the Boulder Lakes. Biotiterich gneiss adjacent to the pipe is bleached; chloritization of biotite in brecciated igneous rocks in the pipe is common. All small stocks in this area are associated with minor intrusive breccias along their margins. Prospects and mines in this area have been dug along gold-bearing vein systems concentrated at the margins of these stocks.

The Boulder Lakes area may be underlain by a major hydrothermal system, perhaps an extension of the system that mineralized the Granite Peak area. The presence of such a system is suggested by the probable hydrothermal, gold-bearing fissure veins in the Tidal Wave mining district (Johns, 1961), the presence of numerous sulfide-bearing stocks containing locally abundant fluorite and sparce tourmaline, by the recorded production of copper ore from the Snyder mine area, and by the weakly mineralized breccia pipe nearby. A moderate potential for base-metal resources is present east of the Boulder Lakes, within the roadless area.

\section{Precious metals}

Mines having recorded gold and silver production are outside the roadless area (Tansley and others, 1933; Johns, 1961), but some, such as those in the Boulder Lakes area (fig. 2), are adjacent to it. Samples from veins in the Boulder Lakes area show as much as $35 \mathrm{ppm}$ gold in Bear Gulch and $700 \mathrm{ppm}$ silver east of the Boulder Lakes, in the roadless area (O'Neill, 1983b). The anomalously high concentrations in vein material and the production history of the district indicate a potential for gold resources in this and adjacent areas. Gold is probably the only primary ore that can be readily exploited by small-scale underground mining methods. The Tidal WaveSheridan mining district in the area around Boulder Lakes shows high potential for gold and silver.
Gold is the only ore recovered from the presently active Nicholson mine, located along the northwesttrending Bismark fault zone and directly north of Granite Peak (fig. 2). Gold reserves at the Nicholson mine appear to be restricted to the mineralized parts of the Bismark fault zone; additional ore, if present, would most probably be found along the northwestward or southeastward trace of the fault zone. The area around the Nicholson mine, including the Moggolian mine, and the Lester Baker and Baugus Hughes prospects, has high resource potential for gold.

The Strawn Mine (fig. 3) was opened along a vein that bears free gold in a thin contact metasomatic zone in the Cambrian Meagher Limestone. This vein can be followed southward into the roadless area. The vein has been claimed by the operators of the Strawn mine for a distance of nearly $3,000 \mathrm{ft}$ south of the main workings. Mineralization at the Ohio Lode mine is similar to that at the Strawn mine to the north in that ore is localized along bedding adjacent to an igneous sill.

Mineralization along the Mammoth fault appears to be mainly restricted to areas southeast of the Mammoth mine, and outside the roadless area; however, some gold reserves are present directly northwest of the mine and may extend a short distance into the roadless area.

Platinum group metals and cobalt, nickel, and chromium

Samples from small pods and lenses of ultramafic rock, possible hosts for cobalt, copper, nickel, chromium, and platinum deposits, were found to contain no significant amounts of these metals (Bruce Lipin, written commun., 1980).

\section{Nonmetallic resources}

Talc.-Talc prospects in the Tobacco Root Mountains, as reported by Berg (1979), are outside the roadless area, along Carmichael Creek and directly east of Wisconsin Creek (fig. 3). Talc has not been reported as present in the roadless area and was not seen during field mapping. Calc-silicate rock and marble, the host rocks for talc deposits in the nearby Ruby Mountains (Berg, 1979), were seen in only one minor zone south of Manhead Mountain (fig. 2) and did not contain talc. No potential for talc resources exists within the roadless area.

Construction materials.-A large resource of lime exists in the dolomite and limestone that rim the northwest and north margins of the Tobacco Root Mountains. These rocks are most abundant in the northern part of the roadless area but are not readily accessible. Carbonate rocks are abundant elsewhere in this part of Montana and many easily accessible deposits are much closer to established markets than are those in the roadless area.

Resources of gravel are limited and are confined to small areas of glacial outwash in the roadless area and vicinity, but abundant and readily accessible gravel is present along the Jefferson River and adjacent to major highways.

Oil, gas, and coal.-Deposits of oil, natural gas, and coal are not known, and are not likely to be present in, the roadless area. 


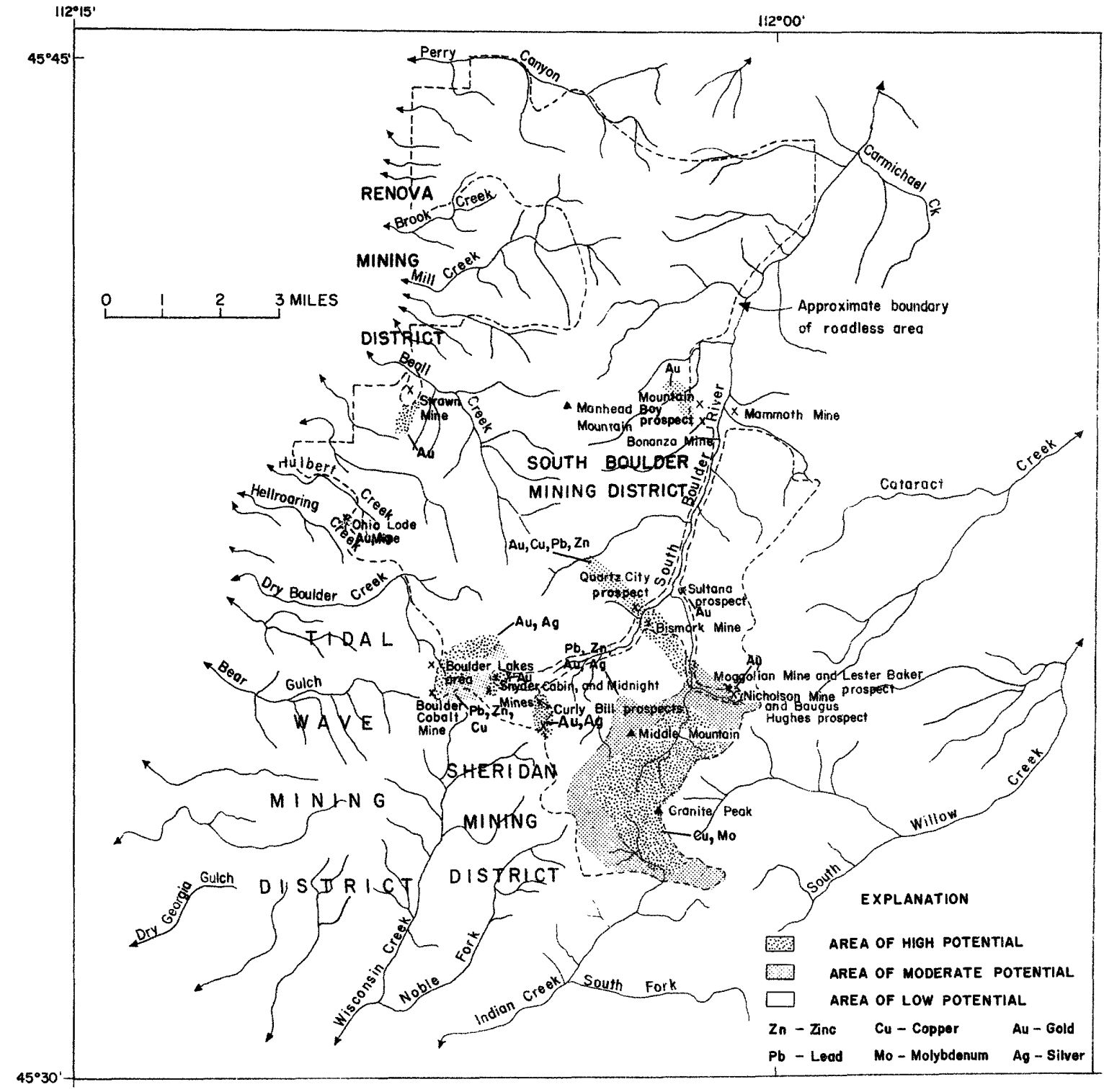

Figure 3.--Map of the Middle Mountain-Tobacco Root Roadless Area showing areas of high, moderate, and low resource potential. 


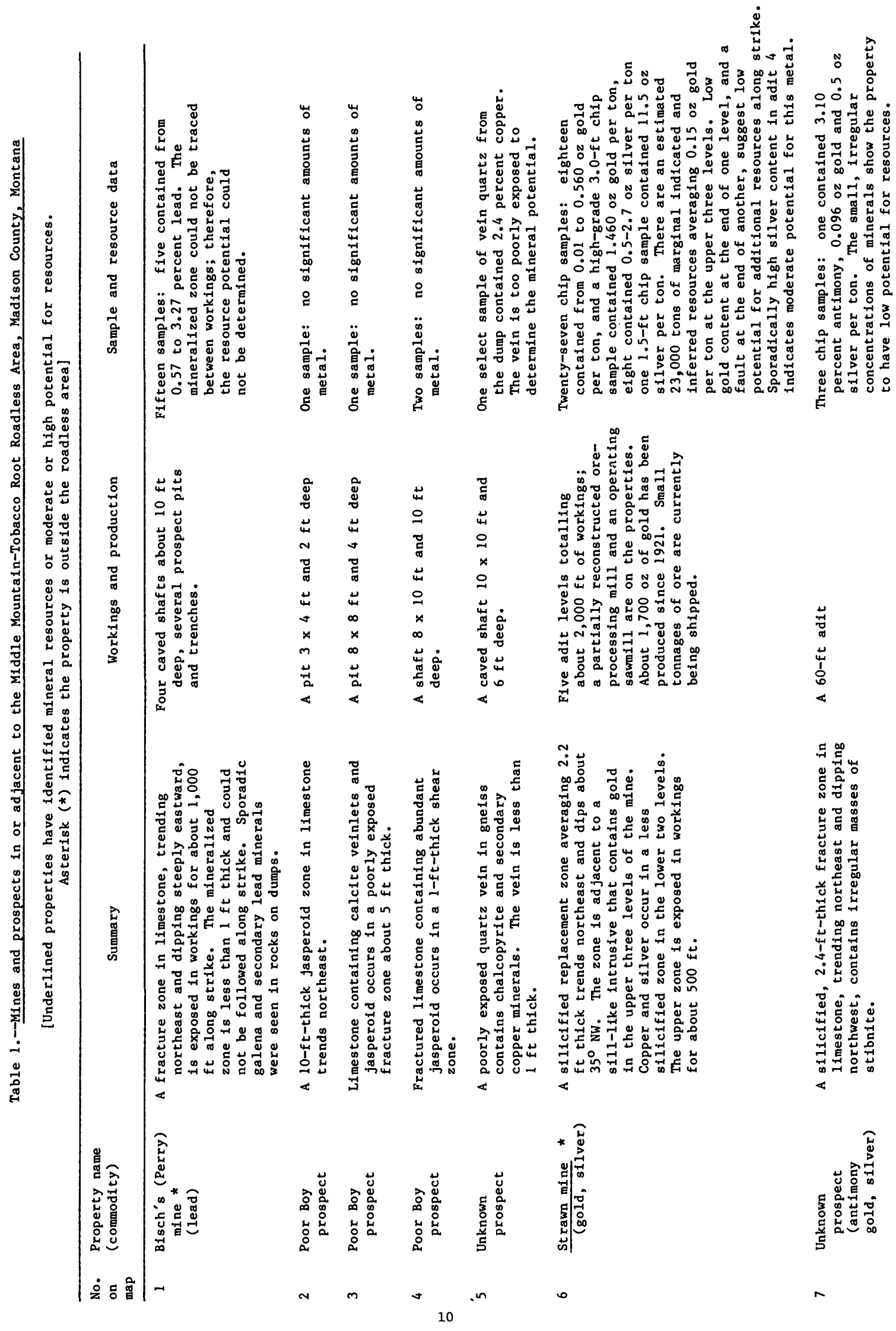




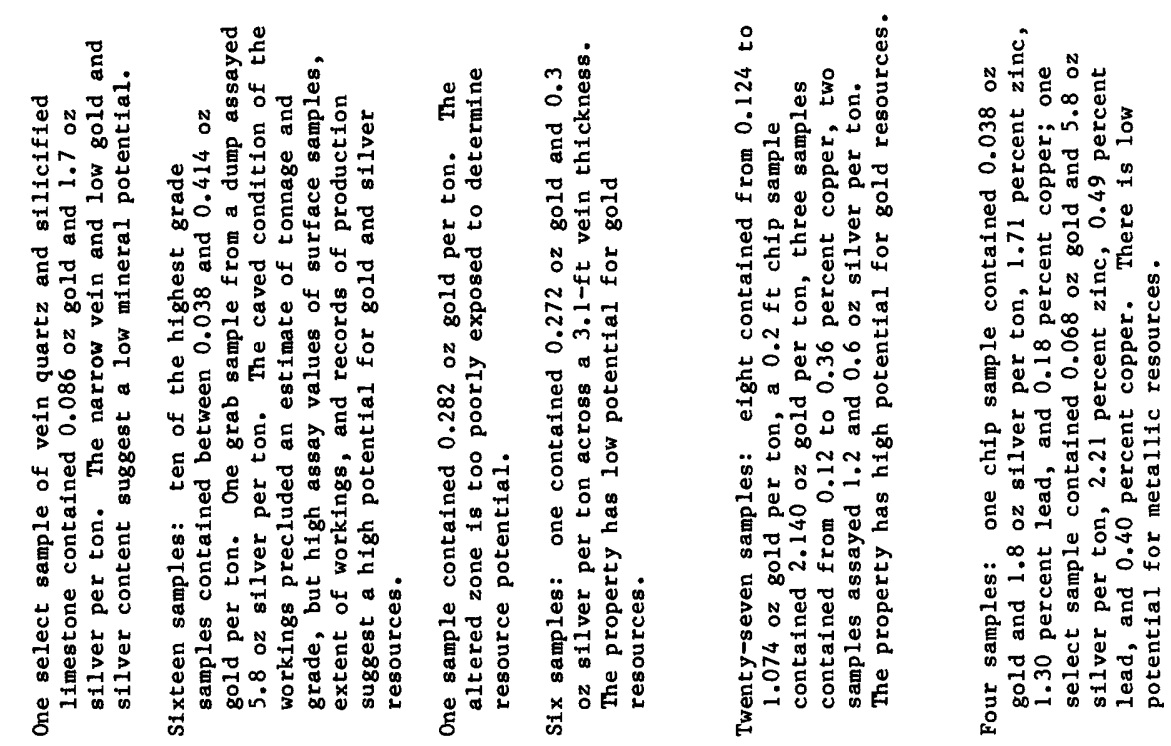

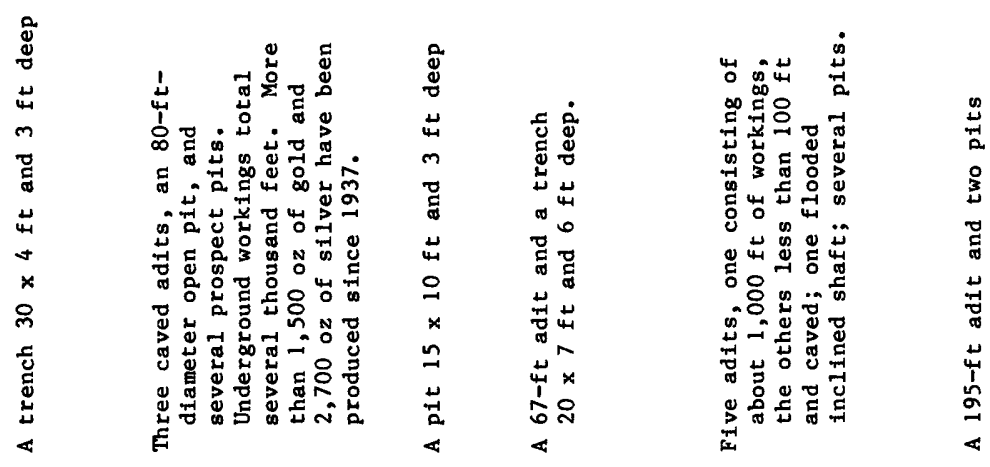
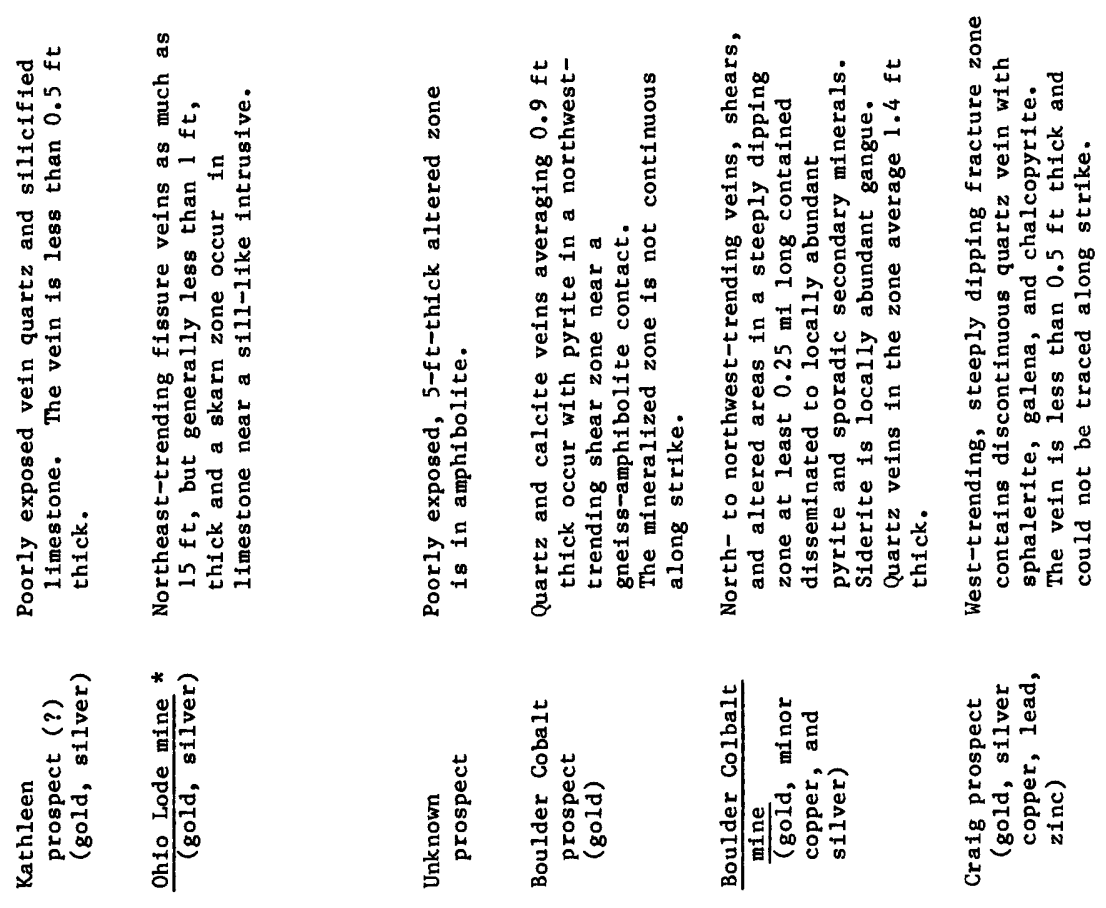

은 


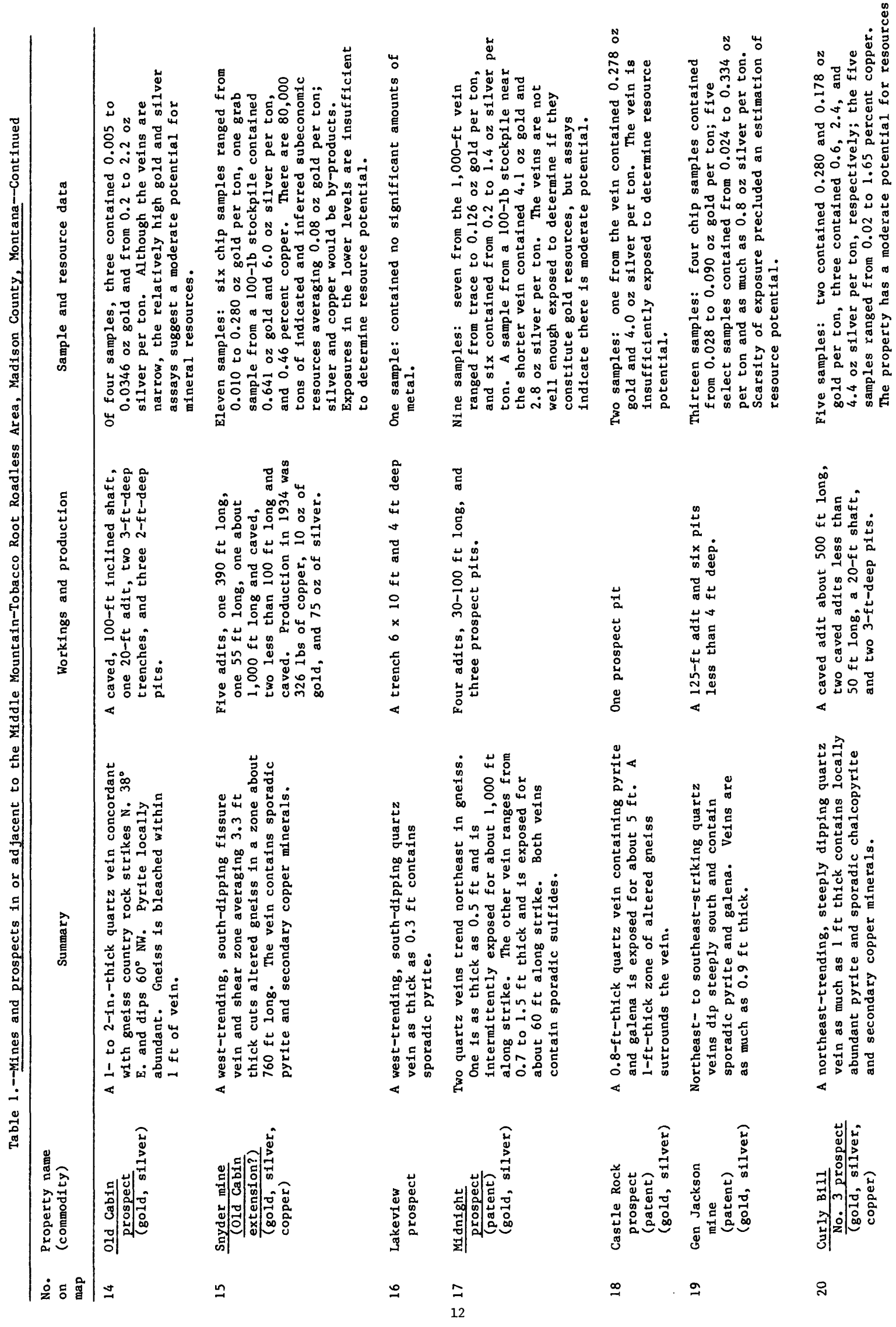




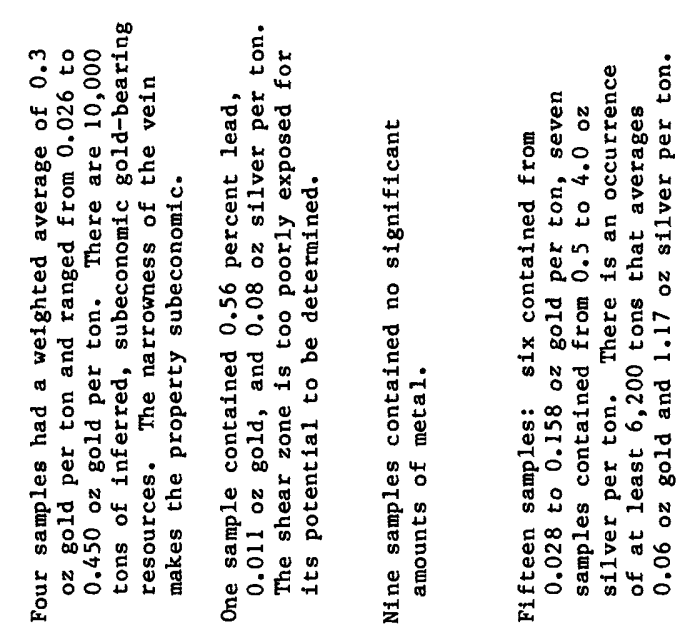

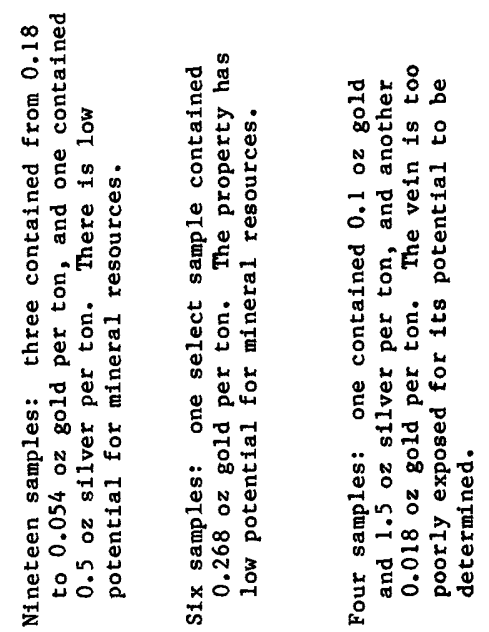
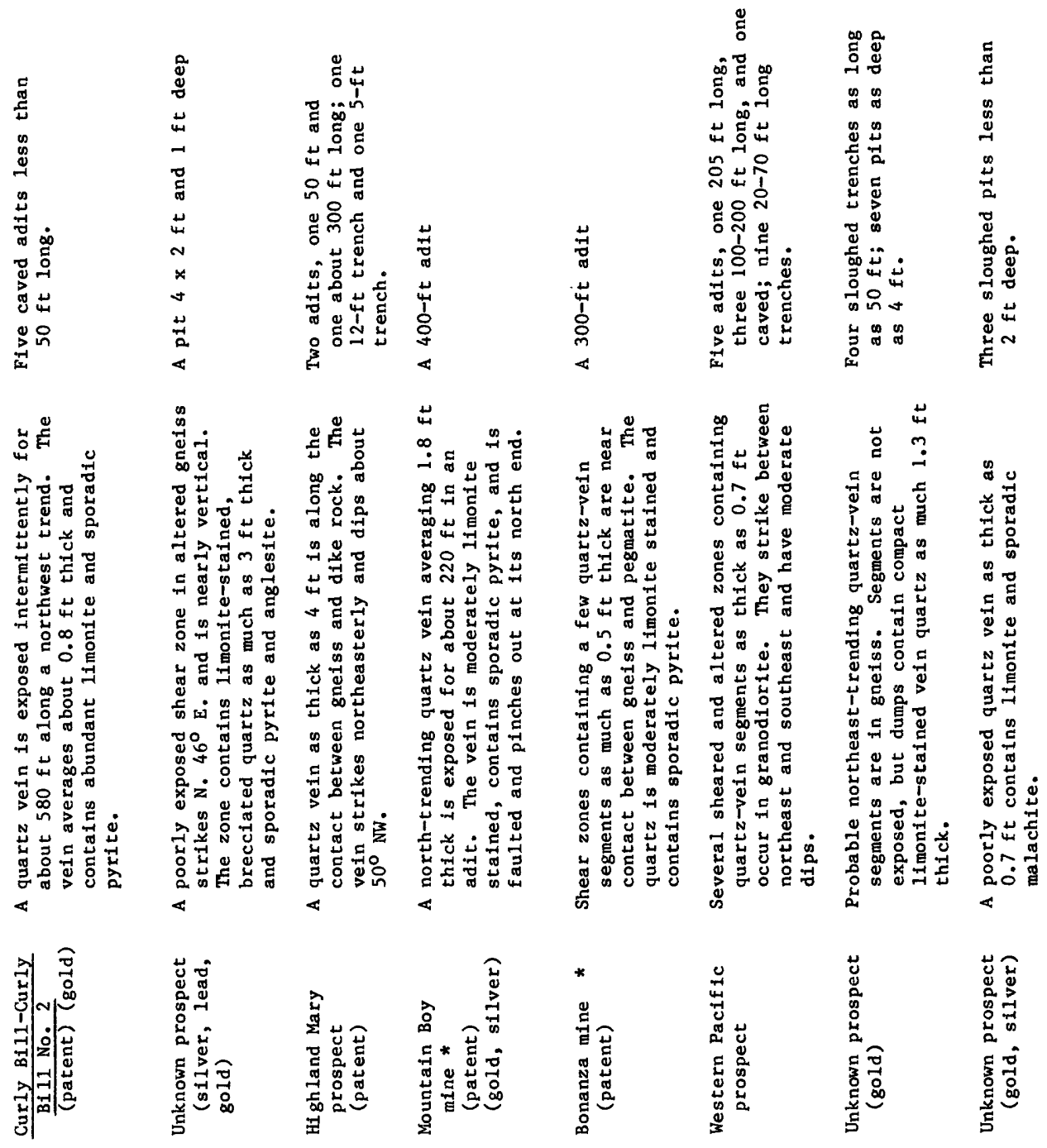

$\bar{\sim}$

ส

N

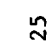

13 

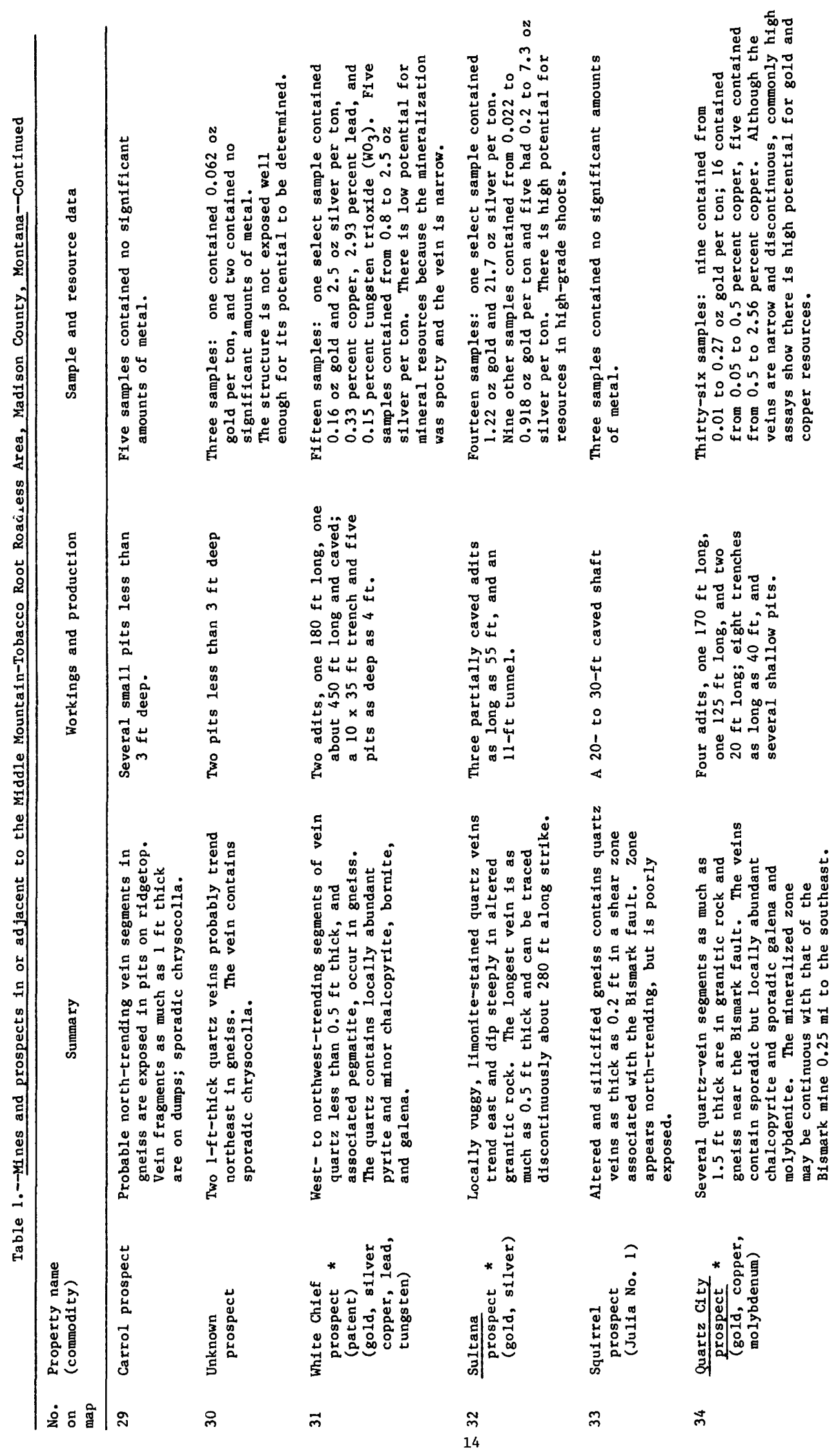

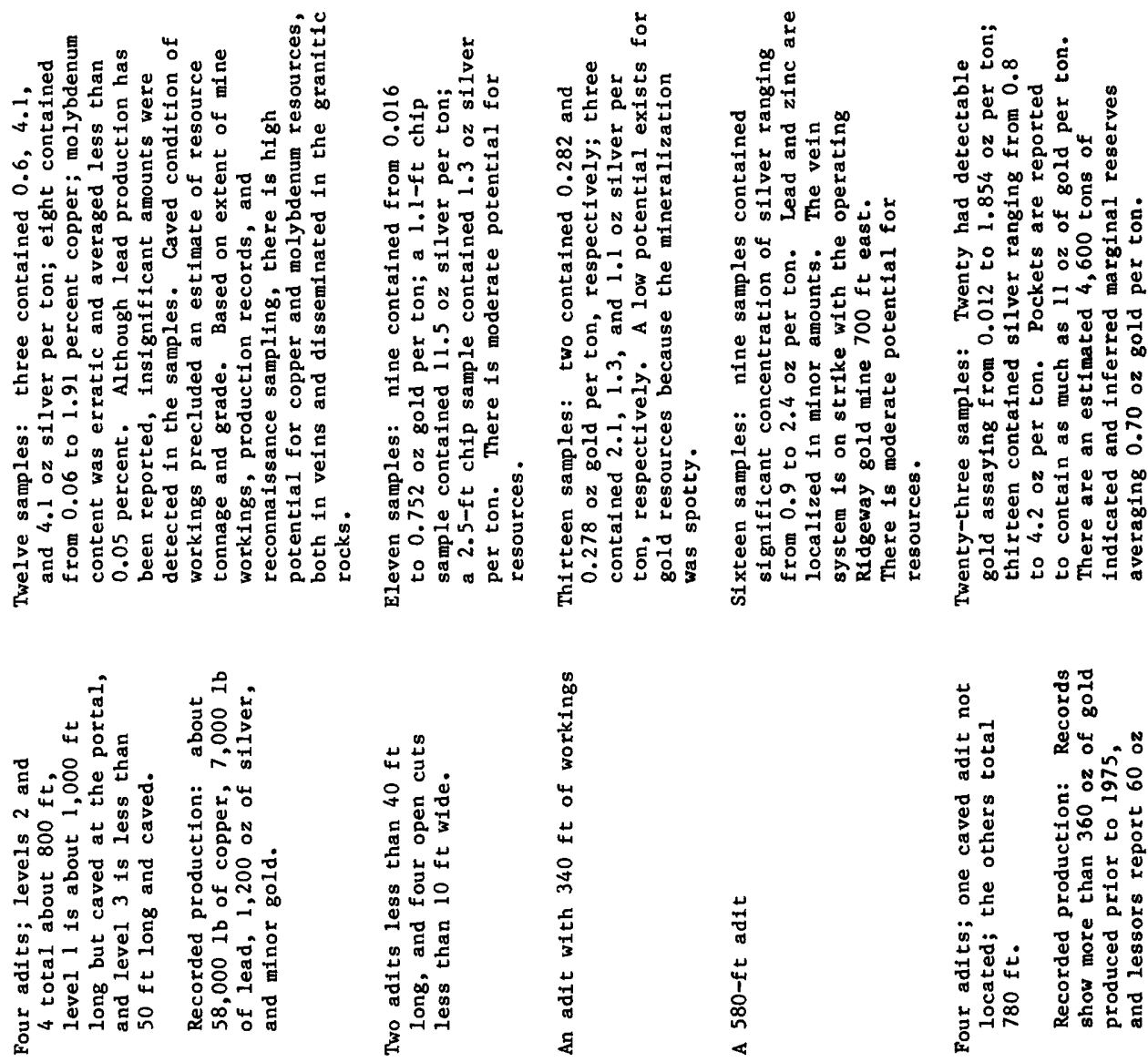

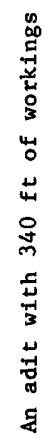
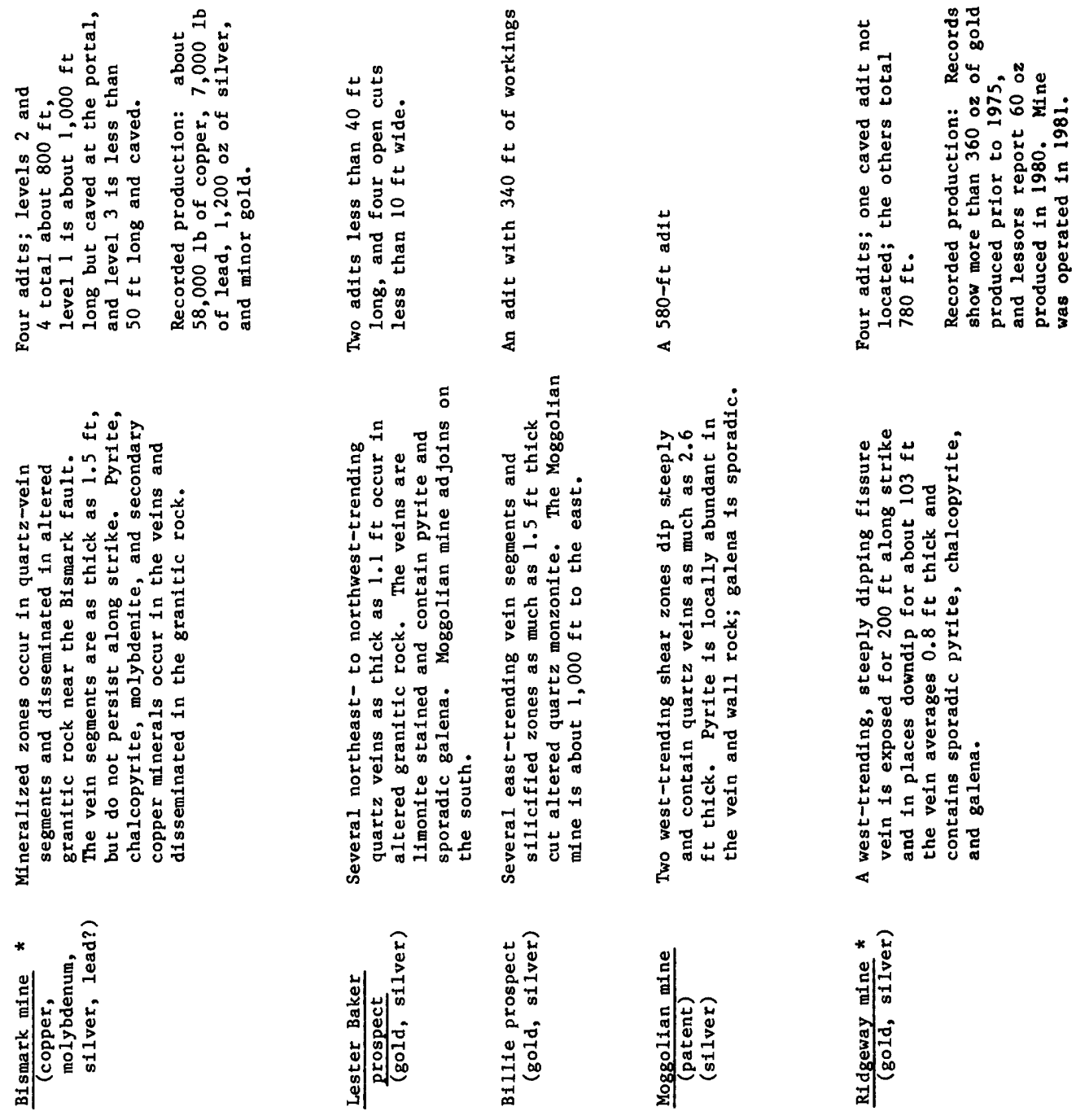

nn

mo

ํ

m 


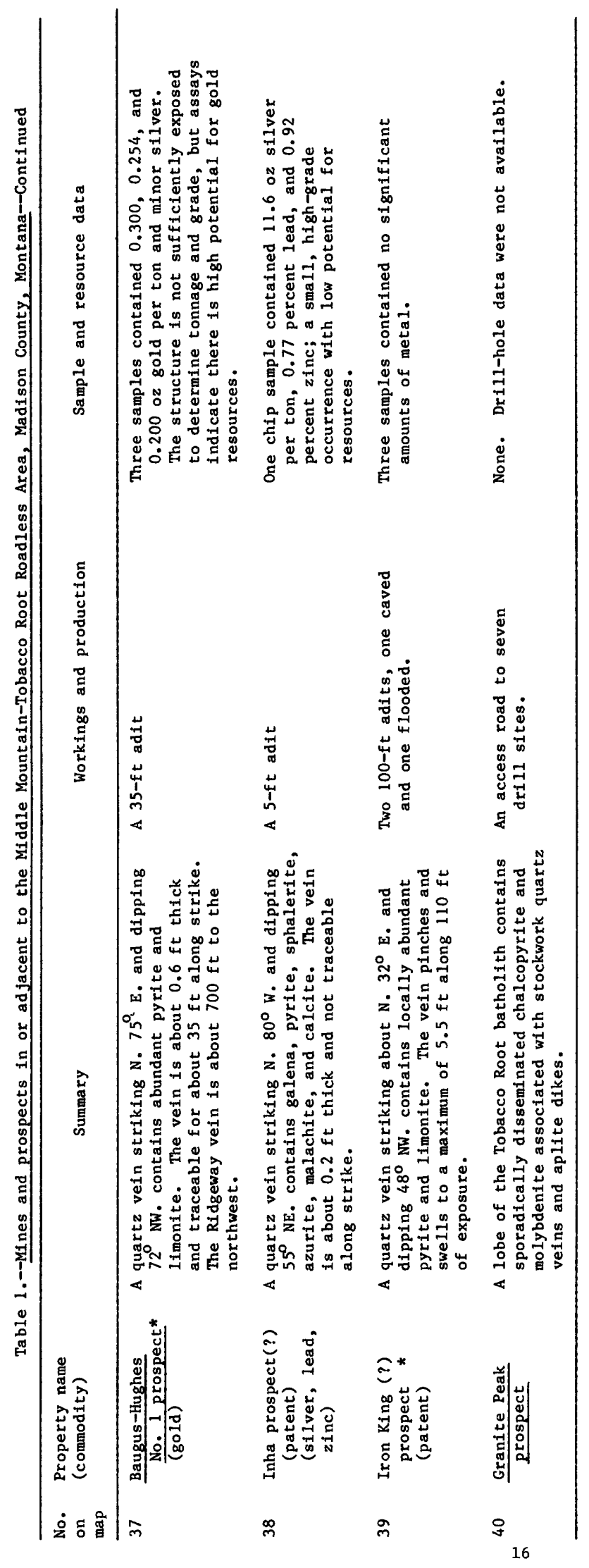


Geothermal resources.-Potential for geothermal energy is restricted to areas of above-average geothermal gradient. The only known hot springs in the Tobacco Root Mountains are at Renova and Potosi; both are outside the roadless area. Hot springs have not been reported as present within the roadless area.

Water resources.-Irrigation water for lands bordering the Tobacco Root Mountains is an important resource presently being widely utilized, especially on the west and north sides of the range. Many of the streams that provide water for irrigation purposes have their headwaters in cirques in or adjacent to the roadless area. The value of this water is obviously very great.

\section{SELECTED REFERENCES}

Alden, W. C., 1953, Physiography and glacial geology of western Montana and adjacent areas: U.S. Geological Survey Professional Paper 231, 200 p.

Berg, R. B., 1979, Talc and chlorite deposits in Montana: Montana Bureau of Mines and Geology Memoir 45, $43 \mathrm{p}$.

Burger, H. R., III, 1967, Bedrock geology of the Sheridan district, Madison County, Montana: Montana Bureau of Mines and Geology Memoir 41, $21 \mathrm{p}$.

Giletti, B. J., 1966, Isotopic ages from southwestern Montana: Journal of Geophysical Research, v. 71, p. 4029-4036.

James, H. L., and Hedge, C. E., 1980, Age of basement rocks of southwest Montana: Geological Society of America Bulletin, v. 91, no. 1, p. I11-I15.

Johns, W. M., 1961, Geology and ore deposits of the southern Tidal Wave mining district, Madison County, Montana: Montana Bureau of Mines and Geology Bulletin 24, $53 \mathrm{p}$.

Mueller, P. A., and Cordua, W. S., 1976, Rb-Sr wholerock age of gneisses from the Horse Creek area, Tobacco Root Mountains, Montana: Isochron/ West, no. 16, p. 33-36.

O'Neill, J. M., 1983a, Geologic map of the Middle Mountain-Tobacco Root Roadless Area: U.S. Geological Survey Miscellaneous Field Studies Map MF-1590-A, scale 1:50,000.

$1983 \mathrm{~b}$, Geochemical map of the Middle MountainTobacco Root Roadless Area: U.S. Geological Survey Miscellaneous Field Studies Map MF-1590B, scale 1:50,000.

O'Neill, J. M., Siems, D. F., Welsch, E. P., and Speckman, W. S., 1980, Geochemical analyses of stream sediments of the Middle Mount ain-Tobacco Root Further Planning Area (RARE II), Madison County, Montana: U.S. Geological Survey OpenFile Report 80-720.

Pardee, J. T., 1950, Late Cenozoic block faulting in western Montana: Geological Society of America Bulletin, v. 61, p. 359-406.

Perry, E. S., 1962, Montana in the geologic past: Montana Bureau of Mines and Geology Bulletin 26, $78 \mathrm{p}$.
Reid, R. R., 1957, Bedrock geology of the north end of the Tobacco Root Mountains, Madison County, Montana: Montana Bureau of Mines and Geology Memoir 36, 27 p.

Reyner, M. L., 1947, Geology of the Tidal Wave mining district, Madison County, Montana: Butte, Montana School of Mines, M.S. thesis, 28 p.

Schmidt, C. J., 1975, An analysis of folding and faulting in the northern Tobacco Root Mountains, southwestern Montana: Bloomington, Indiana University, $\mathrm{Ph}$. D. thesis, $480 \mathrm{p}$.

1976, The influence of Precambrian structural trends on Laramide faulting in the northern Tobacco Root Mountains, southwest Montana [abs.]: Geological Society of America Abstracts with Programs, v. 8, no. 5, p. 627.

1979, A summary of Laramide basement faulting in the Ruby, Tobacco Root, and Madison Ranges and its possible relationship to Precambrian continental rifting [abs.]: Geological Society of America Abstracts with Programs, v. 11, no. 6, p. 301.

Sloss, L. L., and Moritz, C. A., 1951, Paleozoic stratigraphy of southwestern Montana: American Association of Petroleum Geologists Bulletin, v. 35 , p. 2135-2169.

Smith, J. L., 1970, Petrology, mineralogy and chemistry of the Tobacco Root batholith, Madison County, Montana: Bloomington, Indiana University, Ph.D. thesis, 164 p.

Suttner, L. J., 1969, Stratigraphic and petrologic analysis of upper Jurassic-lower Cretaceous Morrison and Kootenai formations, southwest Montana: American Association of Petroleum Geologists Bulletin, v. 53, p. 1391-1410.

Tansley, Wilfred, Schafer, P. A., and Hart, L. H., 1933, A geological reconnaissance of the Tobacco Root Mountains, Madison County, Montana: Montana Bureau of Mines and Geology Memoir 9, 57 p.

Tysdal, R. G., 1976, Paleozoic and Mesozoic stratigraphy of the northern part of the Ruby Range, southwestern Montana: U.S. Geological Survey Bulletin 1405-I, 26 p.

Vitaliano, C. J., Burger, H. R., Cordua, W. S., Hanley, T. B., Hess, D. F., and Root, F. K., 1979, Explanatory text to accompany the geologic map of southern Tobacco Root Mountains, Madison County, Montana: Geological Society of America Map and Chart Series MC-31, 8 p.

Vitaliano, C. J., Kish, S. A., and Towell, D. G., 1976, $\mathrm{K}-\mathrm{Ar}$ dates and $\mathrm{Sr}$ isotopic values for rocks of the Tobacco Root batholith, southwestern Montana: Isochron/West, no. 28, p. 13-15.

Winchell, A. N., 1914, Mining districts of the Dillon quadrangle, Montana: U.S. Geological Survey Bulletin 574, $191 \mathrm{p}$.

Wooden, J. L., Vitaliano, C. J., Koehler, S. W., and Ragland, P. C., 1978, The late Precambrian mafic dikes of the southern Tobacco Root Mountains, Montana--geochemistry, $\mathrm{Rb}$-Sr geochronology, and relationship to Belt tectonics: Canadian Journal of Earth Sciences, v. 15, p. 467-479. 


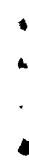

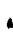

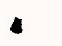

$$
\text { . }
$$
Po 